\title{
CONTENT OF ISLAMIC EDUCATION FOUND IN AL-QUR'AN SURAH AR-RAHMAN
}

\author{
Ali Fauzi \\ STIT Makhdum Ibrahim Tuban \\ email : alifauzi@stitmatuban.ac.id
}

\begin{abstract}
In Al-Qur'an surah Ar-Rahman we find the content of Islamic education which consists of the education of Faith (Akidah), Morality (Akhlak), Islamic Law (Fikih) and Islamic History (Tarikh). However, many moslems just read it, do not know it and do not try to analyze it. Therefore, the researcher chooses the title "Content of Islamic Education Found in Al-Qur'an Surah Ar-Rahman," and formulates the problem, how is the content of Islamic Education Found in AlQur'an surah Ar-Rahman?. The objective of the research is to describe the content of Islamic education found in Al-Qur'an Surah Ar-Rahman. It is hoped that this research will be useful for all.

The approach of the research is phenomenological approach and the instrument of analysis is hermeneutics to interpret the facts, cause and effect based on the available phenomena. The research is qualitative research in form of content analysis and the method of research is descriptive-text-analysis. The data is taken from the words, phrases, sentences and verses found in the Holy book AlQur'an surah Ar-Rahman. The procedure of research is preparation, data collection, and finalization. The researcher then analyzes the data by the way of reducing data, presenting data and concluding data. He also validates them in order that the data he collects are really valid.

The researcher then describes his finding data about the content of Islamic education in the Holy Al-Qur'an surah Ar-Rahman, consisting of the content of Faith (akidah), Morality (akhlak), Islamic Law (Fiqih) and Islamic History (tarikh). The discussion of Islamic education is done deeply and seen from many perspectives. The researcher concludes that in Al-Qur'an surah Ar-Rahman he finds Islamic education mentioned above. He, in this case, suggests the readers in order to read Al-Qur'an and to learn the content more and to try to analyze with the hope that they will get more understanding about it.

Key words: Content, Islamic Education, Al-Qur'an, Surah Ar-Rahman
\end{abstract}

\section{INTRODUCTION}

The word Al-Qur'an has several meanings and one of them is that it is the speech of Allah in form of mu'jizat descended to the prophet Muhammad SAW through the angel of Jibril with the way of reciting and meaning are regulated in a such a way, and it is part of good deed for the reciters started from surah AlFatihah and ended in surah An-Nas (M. Quraish Shihab, 2008: 13). Al-Qur'an is Holy Book for the Moslems containing the speech of Allah descended to the prophet Muhammad SAW. (https://kbbi.web.id/Alquran accessed 15 November 
2019). Surah Ar-Rahman is the name of Allah meaning The All mighty Allah and it is the fifty fifth surah among the surah in the Holy Al-Qur'an consisting of 78 verses and it is the surah of makkiyyah (Ahsin W, 2008: 246). This Surat is called Ar-Rahman meaning The All Generous and The All Loving. Surah "ArRahman" is taken from the word "Ar-Rahman" found in the first verse of surah Ar-Rahman. Ar-Rahman is one of the names of Allah. Major part of surah ArRahman explains the Generosity of Allah to human beings and others. Allah has given all to them during they live in the world and even in the hereafter. The special characteristic of surah Ar-Rahman is found in the sentence "Fa-biayyi alaa'i Rabbi kuma tukadzdzi ban" meaning "so, which of a divine gift of Grace from Allah you do not accept?. This sentence "Fa-biayyi alaa'I Rabbi kuma tukadzdzi ban" which is repeated 31 times are seen in every end of verse tell the enjoyment Allah has given to human beings (Wahbah Az-Zuhaili. 2014).

The verse of surah Ar-rahman with its special characteristic had also been recited by our prophet Muhammad SAW before Allah commanded him to proselytize religious teaching openly. The information is in line with the explanation of Imam Ahmad telling that to us Yahya ibnu Ishaq has told it to Ibnu Lahi'ah, from Abul Aswad, from Urwah, from Asma the daughter of Abu Bakar who told that she had ever heard Rasulullah Saw., in his prayers recited one pillar of Al-Qur'an before he proselytized religious teaching openly. Meanwhile, the Polytheists listen to it as it is told in the Holy Qur'an "So which of a divine gift of Grace from Allah you do not accept?" (M. Abdullah. 2007). Surah Ar Rahman has superiority and excellence. Owing to it, Rasulullah said: "those who recite surah Ar-Rahman, Allah will like his/her weaknesses and bestow blessing on them." From Imam Ja'far Ash-shadiq said: "those who recite surah Ar-Rahman, and when he/she recites the sentence 'Fabiayyi âlâi Rabbikumâ tukadzdzibân', and says: Lâ bisyay-in min âlâika Rabbî akdzibu (no enjoyment you give, I do not accept), if he reads in the night and he dies at the night, so he dies a martyr's death ( be guaranteed immediate admission to heaven ); if he reads in the day and he dies, so he dies like a martyr's death.” Further, Ja'far Ash-Shadiq said:“ Do not forget to read surah Ar-Rahman, wake up night and read it, this surah will not make the munafiqun has peaceful life, you will meet Allah in the doomsday, His 
profile is like human being but it is beautiful profile who has fragrant aroma. In Doomsday, no one can stand nearer before Allah than him" (Ahmad bin Muhammad Barqi. 1371H).

Surah Ar-Rahman is started with the verse showing the proof, sign and manifestation. Sign is a thing which represents or refers to others and sign may function if anything can be interpreted as a proof related to the thing represented. Language is the system of symbols which has two closed elements that is a thing used as a sign which may be in form of sound or symbols and a sign which is the element of conceptual or meaning in the sign (Abrams dalam Burhan Nurgiyantoro, 1998:4). First proof and sign is that Allah The Merciful teaches human beings about Himself through Al-Quran (al-Mizan). Meanwhile, manifestation is the sign which function to think and to feel to object found in the text relationally which is difficult to differ (Abrams dalam Burhan Nurgiyantoro, 1998: 42-43). First manifestation is that Allah is the light of His Dzat and the light of knowledge. Non-moslems want to extinguish the light of Allah and His commands but Allah does not permit it because "Allah Himself is the light of universe" (QS. An-Nur: Verse 5). Surah Ar-Rahman is ended with the sentence "The All Blessing" (tabaraka) meaning one of the names of Allah. The All Blessing is one of the names of Allah. Whenever Human beings call the name of Allah, Allah will come to their houses-the place of someone who calls Allah.

Meanwhile, education is etymologically from Greek language consisting of the words "Pais" meaning someone and "again" meaning to guide. Education (paedogogie) means guidance given by someone (Abu Ahmadi dan Nur Uhbiyati, 1991: 69). Education is the act of transferring knowledge by the teacher to the students in order that they will be prepared to face the life. Education is the aspect which has prominent role in forming generation to have personal strength (Zuhairini, 2004: 1). There are three terms of Islamic education. They are altarbiyah, al-ta'lim, and al-ta'dib in which they have each own characteristics. We also find other terms like tabyin, tadris and riyadloh, but not all the terms are suitable and can represent the basic meaning of Islamic education (Shofan, 2004: 38). Furthermore, the term Islamic education in the context of Islam refers to the terms of al-tarbiyah, al-ta'dib and al-ta'lim. Among the terms, the most popular 
and often used is the term of al-tarbiyah, while the term al-ta'dib and al-ta'lim are rarely used whereas the term has been used since the birth of Islamic education. In certain aspect, the three terms have difference, either textually or contextually. Therefore, it is necessary to discuss the three terms based on the several arguments and the experts' opinion (Al-Rasyid dan Nizzar, 2003: 25).

The first is Al-tarbiyah. The term tarbiyah in The Dictionary of Al-Munjid is taken from the word rabba-yurabbi-tarbiyatan meaning the growing plants. According to Muhammad An-Naquib Al-Attas quoted by Munardi, the word "tarbiyah" basically means to bring up, to carry on, to emphasize, to develop, to keep up and to produce things ready for used (2004: 2-3). The second is Al-Ta'lim. The term of al-ta'lim is etymologically from the Verb "allama" meaning to teach. So al-ta'lim may mean "teaching", in popular Arabic it is stated tarbiyahwa ta'lim meaning "education and teaching", meanwhile, the Arabic of Islamic education is "al-terbiyah al-Islamiyah". The word ta'lim according to the language has basic meaning: (1) from the word "مليق "ملع ملعي" meaning to to give a sign, and (2) from the basic word "ملع ملع understand and to sign. The term al-ta'lim which is also used in making the concept of education in Islamic education means: first, al-ta'lim meaning the process of continuously learning since human beings were born through listening, seeing, and feeling to the limit of age. Second, the process of al-ta'lim does not only discuss things in the scope of cognitive, but it also discusses things in the scope of psychomotor and affective. This meaning tells that ta'lim in education does not only includes intellectuality but also cover morality and action done in the process of learning done. That is why al-ta'lim does not only include and develop knowledge but also develop the aspect of behavior and action based on the knowledge and life (Munardji, 2004: 41-43). The third is Al-Ta'dib.

Al-ta'dib which is often called politeness, morality, ethics or akhlak. Alta'dib which is the same with morality may mean education of civilization or culture. It means that educated people is civilized people, the qualified civilization can be reached by education. Al-ta'dib, in forming civilization and politeness is divided into four kinds: (1) al-ta'dibadab al-haqq, education of spiritual politeness which contains truth; (2) al-ta'dib adab al-khidmah, education 
of spiritual dedication in which human beings must dedicate themselves to their Allah; (3) al-ta'dib al syariah, education of spiritual politeness in the Islamic law syariah, in which the way of doing it has been told in Divine Revelation (wahyu); (4) al-ta'dibadab al shuhbah, education of spiritual politeness in friendship, respecting one another (Abdul Mujib dan jusuf Mudzakkir, 2006: 20-21).

After the term al-tarbiyah, al-ta'dib, dan al-ta'lim, are explained, they can be analyzed. If it is seen from the side of the emphasis, we find the difference one another, but from the content we find interconnection that is to bring up and to educate children. Al-ta'dib stresses on the achievement of right knowledge in human beings in order to get real good deeds and good behaviora. While altarbiyah, focuses on the guidance of children in order that they develop their potency, have basic morality and develop it completely. Furthermore, Al-ta'lim, stresses on the transferring of good knowledge, understanding, responsibility, and the establishment of integrity to the children. Al-ta'lim includes the aspects of knowledge and skill needed in life and good guideline of behaving. Based on the description of the three terms, it is seen that the terms Al-ta' dib, altarbiyah, dan al-ta'lim can be used together in Islamic education (Ridlwan Nasir, 2005: 53).

Islam is the revelation religion which guides human beings in all aspects of life based on Al-Qur'an and Hadits which send them to the high intention. Islam is a system of faith, Islamic law and morality which manage life of human beings in all aspects (Muhammad Daud Ali, 2017: 50-51). The word Islam in "Islamic education" refers to the certain education, that is education based on Islam. Islamic education is aimed at more mental and spiritual behavior in order to be manifested in form of good deeds either goodness for himself or for others. Islamic education must be implemented not only in form of theoretically but also practically because Islamic teaching does not separate between faith and good deed. Therefore, Islamic education covers education of faith and deed because Islamic teaching contains attitude and behavior of individual and social to get better life together. Islamic education is for individual and social education, in 
which formerly, it was under the responsibility of prophets and Rasul but now it must be taken by Ulama and men of Islamic scientists (Daradjad,dkk, 2008: 28).

If we examine closely, Surah Ar-Rahman contains several elements. Firstly, it contains Faith (Akidah). Allah teaches human beings to speak well; trees and plants obey Allah, the universe and all in it are the bless from Allah given to human beings. Secondly, it contains morality (Akhlak). It refers to the deeds of human beings and to warn in form of guidance. Thirdly, it contains Islamic Law (Fikih). It contains thing leading us to measure, to weigh something justly. Fourthly, it contains Islamic history (tarikh). It contains the history of human beings and genies who are under the control of Allah. Many human beings and all genies do not thank Allah for the bless endowed upon them. Many things happen and will happen as Allah's will (Az-Zuhaili, 2014: 226-227). It is sure that the content of Islamic education - the effort intentionally and planly in preparing students to know and to interpret and to believe in Islamic teaching and to do in their daily life (Daradjat,dkk, 2005: 45) such as faith (Akidah), morality (Akhlak), Islamic Law (Fikih) and Islamic History (Tarikh) is automatically found in it.

The content of Islamic education either stated or unstated in the Al-Qur'an Surah Ar-Rahman is seen as follows: First, the content of Faith (Akidah) education in Al-Qur'an Surat Ar-Rahman is found in several verses and one of them is in the third verse that is Allah creates human beings; Second, the content of morality (Akhlak) education is found in the Al-Qur'an Surat Ar-Rahman are seen in several verses and one of them is the sixtieth verse that is there is good reward except the goodness itself. Third, the content of Islamic Law (Fikih) education related to the way to measure and to weigh justly. The fourth, the content of Islamic History (Tarikh) education in the Al-Qur'an surat Ar-Rahman is seen in several verses and one of them is in the fourteenth verse that is $\mathrm{He}$ creates human beings from the clay and then it is connected with the fifth verse that is He creates genie from the fire (Az-Zuhaili, 2014: 226-227). However, many moslems just recite the Al-Qur'an and do not know about those contents. Therefore, the researcher is interested in discussing it and tries to describe the content of Islamic education found behind the beauty of language and meaning in 
the Al-Qur'an Surat Ar-Rahman. The researcher has also motivation to research it because of the prominence and benefit of reciting Al-Qur'an Surat Ar-Rahman from which he determines to choose the title "The Content of Islamic Education Found in Al-Qur'an Surat Ar-Rahman" as the main discussion and abstraction in this research.

The researcher hopes that it will come up many kinds of discussion about the content analysis found in the Holy book Al-Qur'an and other classical books in the academic institution. To make the discussion easy to do, the researcher formulates the problem; How is the content of Islamic education found in the AlQur'an surah Ar-Rahman?. By this, the objective of the research is that; to describe the content of Islamic education found in the Al-Qur'an Surah ArRahman. Of course, by this research, the researcher hopes that this research has usefulness for the readers. It at least will be the additional reference and of reading material to add knowledge which enable to have new inspiration and new research.

\section{RESEARCH METHODOLOGY}

The approach of this research is phenomenological approach in which the researcher tries to find and to interpret the facts and the causes of things based on the phenomena and the researcher's view although it may be subjective (Arifin, 1994: 46-47). On account of the fact that the researcher uses phenomenological approach and he must interpret phenomena in the text, so he uses hermeneutic - a method in understanding and in interpreting phenomena in the text by the use of language - in the discussion and the description of data (Ratna, 2004: 44-45). It means that the researcher tries to observe the events, and phenomena reflected on the words, sentences, and verses in the Al-Qur'an Surah Ar-Rahman based on his own interpretation. In the research, the researcher functions as the main instrument, the data are analyzed inductively, stresses on the process more than result, focuses on the main points discussed in the research finding and recapitulated based on the criteria and the valid data are discussed simultaneously (Moleong, 2017 4-8). Qualitative research uses approach which orientate on the natural symptoms, so it cannot be done in the laboratory but in the relation with the text (Nazir, 1986:159). Theoretical orientation becomes the basic of thinking 
to understand the meaning and to interpret classical text or social reality in the past in order to be appropriate for each time. Hermeneutic includes three subjects related one another, the world of the text, the world of the author and the world of the reader in which they have their own scope supporting each other in understanding text (Mulyono, 2012: 100).

The research is library research in form of content analisis. It means the researcher analyzes the content of Al-Qur'an Surah Ar-Rahman and describes the aspects of education in the text as material analysis to prove that in Al-Qur'an Surah Ar-Rahman we find education of faith (Akidah), Morality (Akhlak), Islamic law (Fikih) and Islamic History (Tarikh). The researcher does the research in three phases. The first is data reduction- the process of selecting, focusing and transforming raw data in Al-Qur'an Surah Ar-Rahman. The second is data description- describing all finding data gat membantu enabling him to understand the phenomena in the text. The third is data conclusion - done after doing data verification (Miles and Huberman, 1984: 48-51). He also finds data from many literatures to get theory, principle, law, used to analyze it (Suharsimi Arikunto, 2002:23). The method used is deskriptif-textual analysis. It is done because the object he analyzes is in form of language in verses of Al-Qur'an Surah ArRahman containing Islamic education (Bogdan dan Biklen dalam Moleong, 2017: 3). The method of analysis describes phenomena in the text through collecting data, analyzing data interpreting data, so that the research will valid and reliable (Surahmad, 1972: 131).

The Data is in form of phenomena, facts, information, and source of data is Al-Qur'an Surah Ar-Rahman as primary data and other books related to it as the secondary data. To interpret, he uses many books of such as Tafsir Ibnu Katsir, Tafsir Al-Munir dan Tafsir Al-Misbah as instrument to analyze (Arikunto, 1989: 102). In collecting data, he uses the technigue of observation and documentationtechnique of observing and recording systematically on the aspects in the symptoms in the object of research (Nawawi dan Martini, 1992:74). By this technique, the researcher understand and know the content of Islamic education found in the Al-Qur'an surah Ar-Rahman and the researcher himself acts as main instrument. The researcher combs the text Al-Qur'an Surah Ar-Rahman and 
arranges systematically the quotations in order to be easy to analyze. In analyzing data, he does it through, data reduction, data display and Conclusion Drawing/verification. In fact before data conclusion, the researcher must recheck many times on the validity of them by crosschecking, confirming, and sinchroning data in the text of Al-Qur'an Surah Ar-Rahman.

CONTENT OF ISLAMIC EDUCATION FOUND IN AI-QUR'AN SURAH AR-RAHMAN

\section{Content of Faith (Akidah)}

Content of education of faith (Akidah) which is related closely to the Islamic foundation may be in form of the oneness of Allah all moslems must believe before they do religious teaching (Hadasi Nawawi, 1993: 326). The learning of Akidah which is part of Islamic education stresses more to the aspect of affective either in establishing the aspect of believing in Allah or the aspect of respecting human beings to the students. It means that theoretically in learning students not only concentrate cognitively to the materials but they are also able to change their knowledge of akidah to become more meaning more useful and may implement in the daily behavior (Muhaimin, 2004: 313). Content of beliefe or Akidah is found in the Al-Qur'an surah Ar-Rahman verses 1-6, verses 26-27 and verses 78 below.
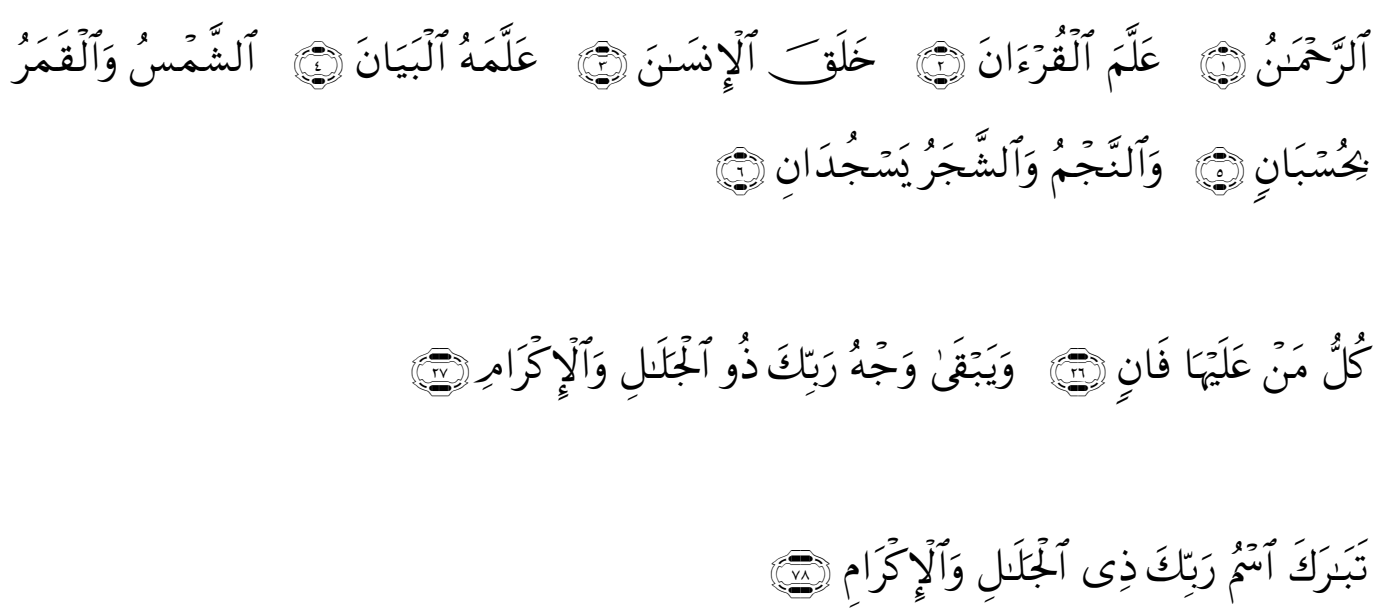

The above quotation has 9 verses containing the education of faith or Akidah. The verses 1-6 mean: (1) (Allah) The Merciful, (2) who has taught AlQuran, (3) He creates human beings, (4) teaches to speak well, (5) the sun and the 
moon (revolve) based on the calculation, and (6) and all kinds of plants and trees obey to Allah (Wahbah Az-Zuhaili, 2014: 227). The verse teaches us to believe the existence of Allah The Merciful, teaches us Al-Qur'an, Allah creates human beings, teaching to speak well, manages the orbit of the sun and the moon and the trees obey to Him. Meanwhile, verses 26-27 have meanings: (1) all which exist in the earth will be destroyed, and (2) but the face of your Allah who has His greatness will exist for ever (Wahbah Az-Zuhaili, 2014: 240). The verse teaches us to believe that all will be destroyed and only Allah who has the greatness and superiority which exist for good. Verse 78 means "The great name of your Allah, the owner of superiority and greatness" (Wahbah Az-Zuhaili, 2014: 260). The verse teaches us to believe that it is only Allah who has the greatness and the superiority.

Content of education of faith (Akidah) presented above becomes the subject given to the students. It is related to the foundation of Islam in form of the knowledge of oneness of Allah. It is kind of belief in the oneness of Allah all Moslems must believe before they do religious teaching. The learning of Akidah is the part of Islamic education which put the aspects of afective, cognitive and psychomotoric which can be implemented in daily life. The discussion of akidah is found in the Al-Qur'an surah Ar-Rahman verses 1-6 and verses ke 26-27. Verses 1-6 means: (1) (Allah) The Generous, (2) who has taught Al Quran, (3) He creates human beings, (4) He teaches to be able to speak well, (5) the sun and the moon (revolve) according to calculated orbit, (6) and the plants and trees, both obey Allah. Verses 26-27 mean: (1) all in the earth will be destroyed, and (2) but the face of your Allah who has eternal geatness and goodness will remain the same for good. Verses 78 means " the all holy of Allah the owner of greatness and holiness". The verses teach us to believe that there It is only Allah who has great generousity, taught Al-Qur'an, created human beings, taught to be able to speak well, managed the orbit of the sun and the moon, defeated the treess, and destroyed the earth. Allah has eternal greatness and holinessan and onli Allah whoo has them in which human being must believe.

\section{Content of Morality (Akhlak)}

Content of morality (Akhlak) is regulation from Allah and it is stated in 
Al-Qur'an and As-Sunnah which regulate the relation of human beings and Allah, the relation of the moslems and the Prophet (Rasul), the relation of human beings and others and the relation of human beings and the nature. In brief, morality includes the morality to Allah, morality to Rasul, morality to others and morality to nature (Zuhairini, 2004: 60). The content of morality is found in The Al-Qur'an surah Ar-Rahman verses 29, 31, 33, 35 and 60, as it is seen in the quotation below.

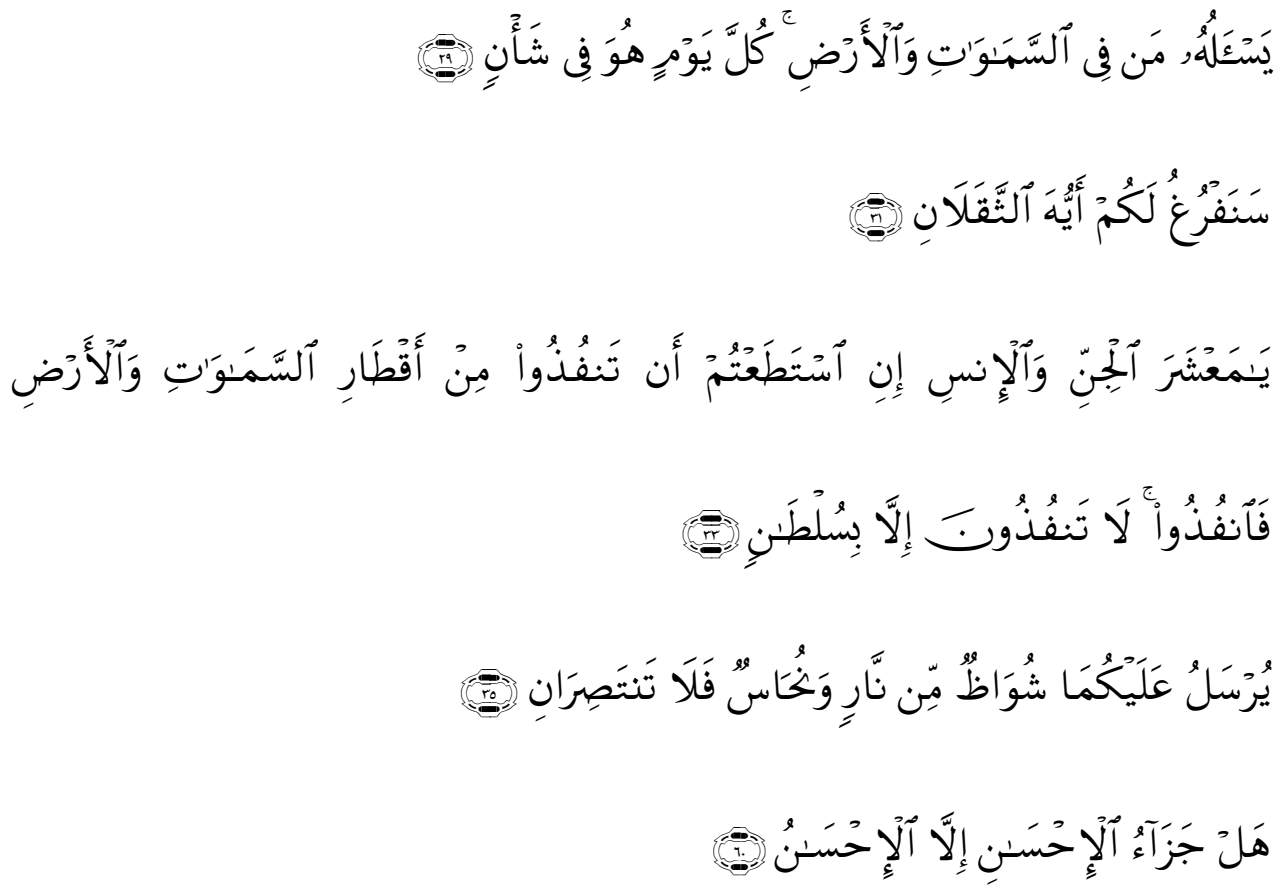

The quotation above contains Islamic education in form of Moral education, sharply moral education of human beings to Allah. They are seen in the verse 29 meaning "Whatever things in the sky and in the earth always ask Allah. Every time $\mathrm{He}$ is in His busy time. Verse 31 means "We will give attention fully to you (man and genie)!". Verse 33 means "For you, a man and genie! whenever you are able to pass through the sky and earth, so do it. You will not be able to do it except you get the power from Allah". Verse 35 means "To you (genie and men), will be sent flame, fire and hot fluit of copper so that you can not save yourselves (from Him)". Verse 60 means "No reward for goodness except the goodness itself".

Content of Morality (Akhlak) is the regulation from Allah found in the 
Al-Qur'an and As-Sunnah which regulates the relationship between human beings and Allah, the relation between the moslems and Rasul, the relation of the same human beings and the relation between human beings and the nature. They are found in the Al-Qur'an surah Ar-Rahman verses 29, 31, 33, 35 dan 60. All verses contain Islamic education of morality (akhlak). It means that the verses explain manner, regulation, and politeness of human beings relating to the relation between human beings and Allah, the relation of human beings and the prophet (Rasul), human beings and others and human beings and the nature manifested in the daily life.

\section{Content of Islamic Law (Fikih)}

The word Fikih or fiqih (Islamic Law) is from the word faqaha meaning "to know" and "to understand". Meanwhile, terminologically, the term syar'i science of fiqih is the science which talk about Islamic Law syar'i amali (practically) in which its power is based on the understanding deeply on the Islamic argumentation taken from (Al- qur'an dan hadits) (Alaiddin Koto, 2004: 2). The experts of Islamic law define fiqih as a group of charitable law regulated in Islam. Furthermore, the experts of Islamic law (fuqaha) divide it into two parts that is, the first, to maintain or to defend law of furu' (secondary law) fully or a part of, and the second, the use of the main material of law either law of qath'i or law of dhani (Kementerian agama RI, 2014: 14). The word syari'ah tells that Islamic law (fiqih) talks about stipulation in form of syar'i that is things from the will of Allah. The word good deed (amaliyah) tells us that Islamic law (fiqih) is only related physically to the deed of human beings. Therefore, things which is not related to the deed like the faith (akidah) does not belong to the area of Islamic law (fiqih). The word Istimbath means that fiqih exists because of the result of hunting, finding, analyzing and the establishing about law.

Fiqih according to harfiah means understanding correctly on what it is meant, therefore, it is prominent to define it as follows:

a. Science of fiqih is a groupf of sciences which have large scope of discussion, compiling many kinds of Islamic law, and have several regulation of life created for ones, community and society (Teungku Muhammad Hasbi 
Ash Shiddieqi, 1997: 9).

b. Science about Islamic law related to the deeds of human beings taken from the respective of Islamic argumentations (Abdul Wahhab Kallah, 2002: 2).

c. Science which discusses law of Syari'ah practically taken from Islamic arguments in detail (Abuddin Nata, 2003: 26).

The success of fiqih education can be seen from the daily life, either in family, schools, or society. In the family, for instance, a child likes regularly praying five times by himself more. That is why, the evaluation of learning fiqih is not only in fprm of written test but also in form of prfactice. Many students theoretically have good gradesin the subject of fiqih but practically they cannot apply the theory in form of prayer (Shalat) well. In the Al-Qur'an surah ArRahman we find the content of Islamic law (fiqih) in the verses 7-9, as they are seen below.

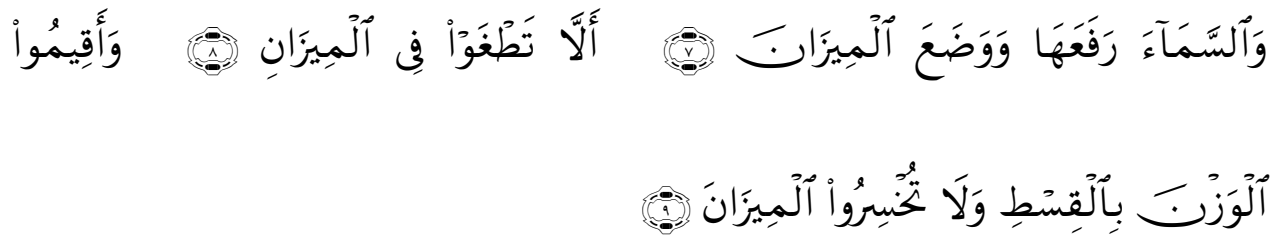

The above quotation contains education of Islamic law (fiqih) about honesty and justice. Verse 7 means "And He has heightened the sky and He has created balance". Verse 8 means "in order that you don not destry the equilibrium" dan verse 9 means "and staright up the balance justly and do not decrease the balance. Menurut istilah syar'i ilmu fiqih ialah ilmu yang berbicara tentang hukum-hukum syar'i amali (praktis) yang penetapannya diupayakan melalui pemahaman yang mendalam terhadap dalil-dalilnya yang terperinci dalam nash (Al- qur'an dan hadits) (Alaiddin Koto, 2004: 2). As a science which talk about Islamic law, fiqih is a group of science which has large scope of discussion consisting of many kinds of Islamic law, many kinds of regulation on life and on human beings behavior based on practically syari'ah argumentations. Verse 7 means "and Allah has heightened the sky and created balance", verse 8 means "in or der that you do not destroy the balance" and verse 9 means "and straight up the balance with logical and spiritual arguments justly and you do not decrease the balance" from which all are the content of Islamic education telling 
about law and justice regulating human beings life so that their life become good, discipline and welfare especially from the aspect of deeds (muamalah).

\section{Content of Islamic History (Tarikh)}

In Kamus Umum Bahasa Indonesia, W.J.S. poerwadarminta says that history or in Islam called tarikh is the sequence of real events or incidents happening in the past. It looks that the definition stresses on the subject of events without connecting to the other aspects. Meanwhile, one event of history must comprehensively be identified who is the doer of history, where does the event happen, and why does the event happen. In other words, in history it finds the object of incidents (What), one who does the incidents (who), time of event (when), place of events (where), and the background of events (why). All the aspects are then arranged systematically and described the closed relationship between them detailly (Nata, 2012: 362). The subject of Islamic law (Tarikh) is a part of the subject of Islamic education lead to prepare students to know, to understand and to interpret the history of Islam which then become the basic of the way of life (way of life) by the activities of guidance, teaching, training, observation and habit. In Al-Qur'an surah Ar-Rahman we find the content of education of Islamic history (tarikh) in the verses 10-24, verses 36-59 and verses 61-77, as they are seen in the quotations below.

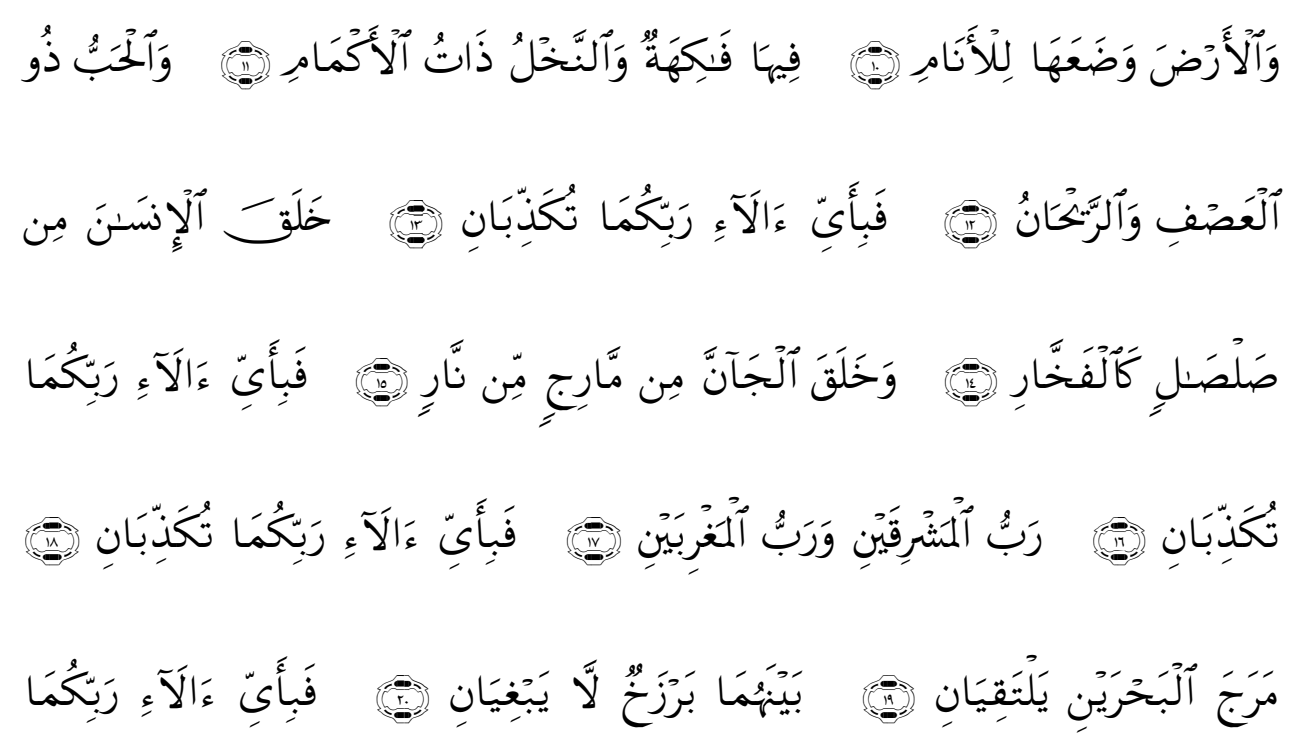




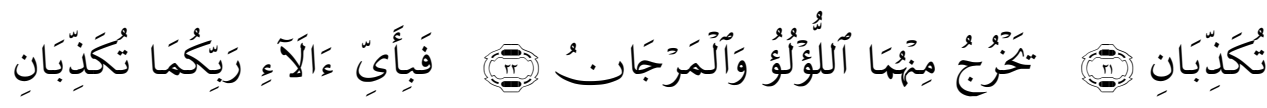

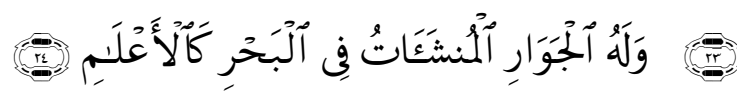

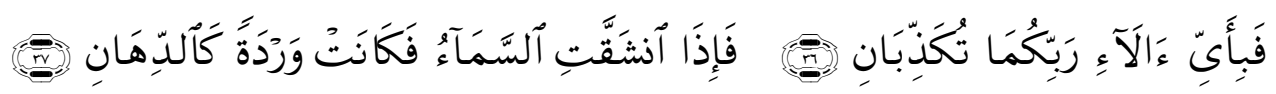

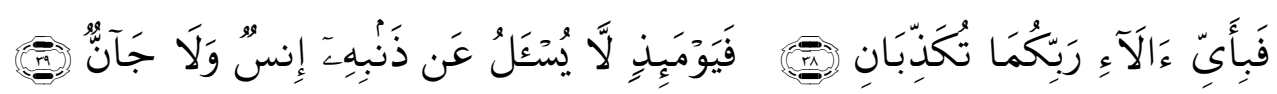

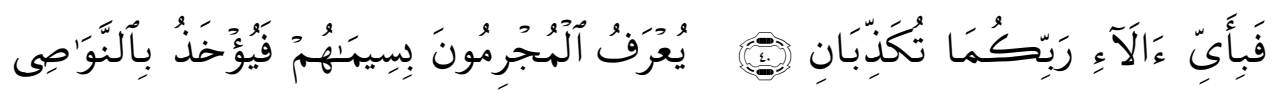

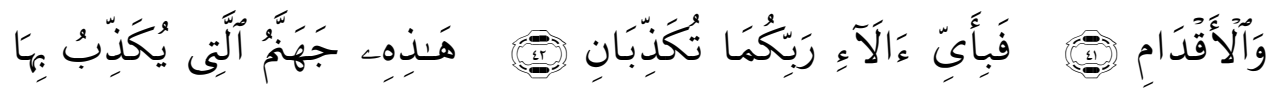

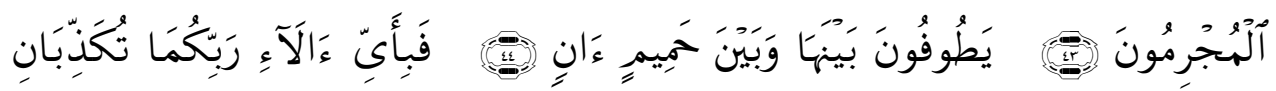

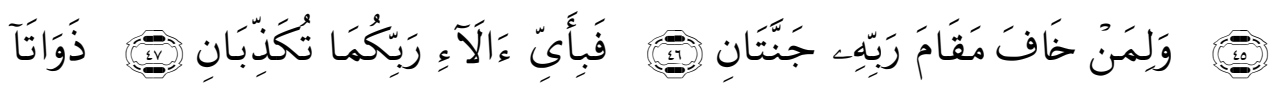

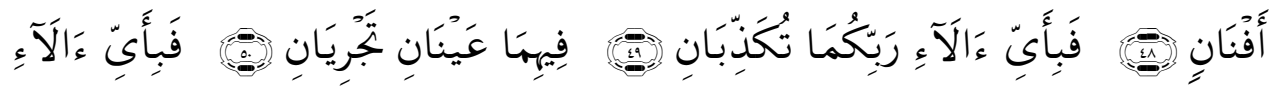

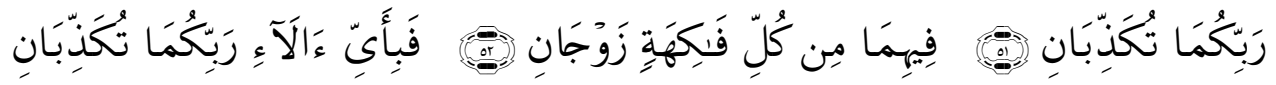

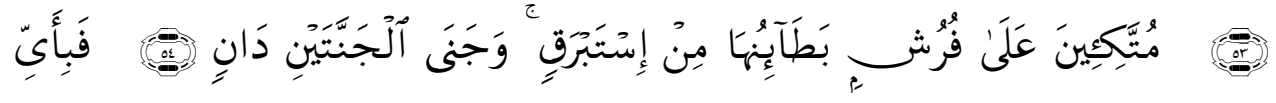

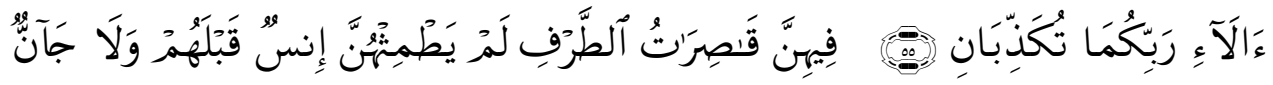

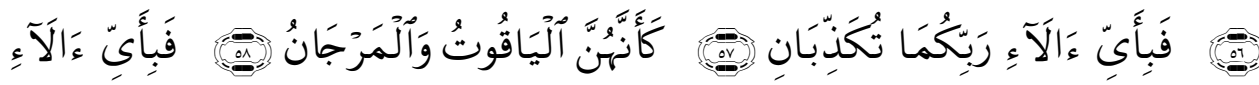

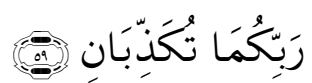




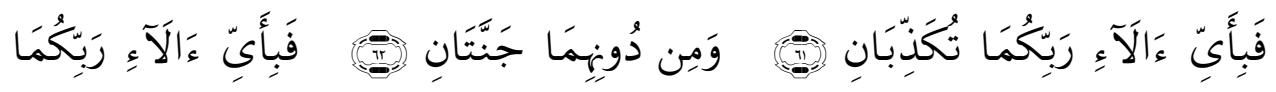

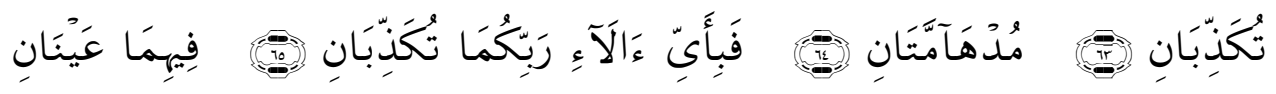

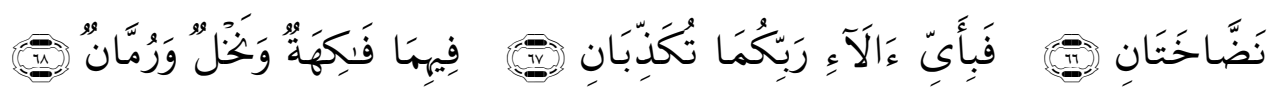

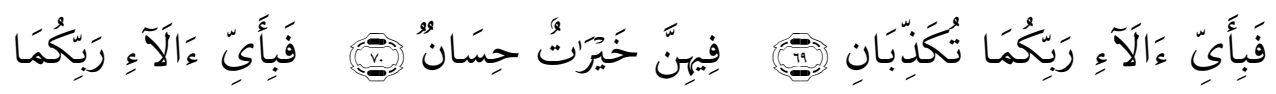

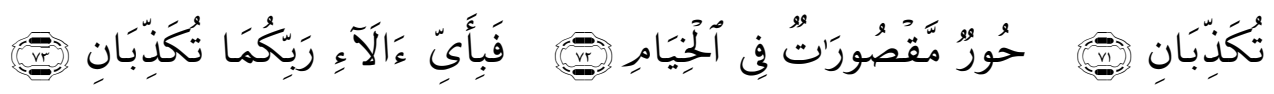

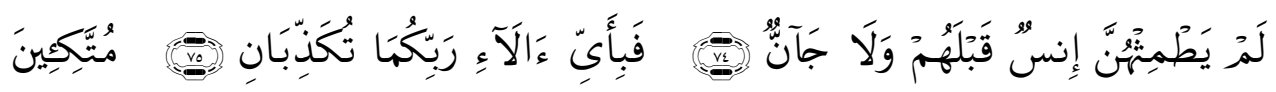

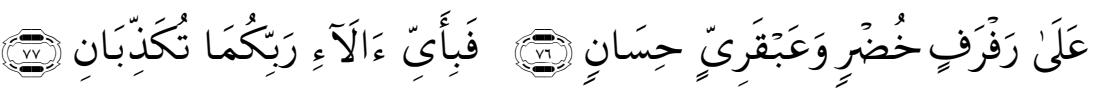

In the quotations above, the researcher finds education of Islamic history (tarikh) that is in verse 10-24 meaning: "And the earth He spreads out for His creature (10), there are fruits and date palm fruits which have beautiful sheaths (11), and the seeds with their calm shell and the fragrant flowers (12), So what enjoyment Allah gives you do not accept? (13), He creates human beings from clay like earthenware (14), and He creates genie from fire without smoke (15), so what enjoyment Allah gives yo do not accept? (16), Allah (keep up) two east and Allah (keep up) two west (17), so what enjoyment Allah gives yo do not accept? (18), He lets the sea runs which then they meet (19), between them there is border they each cannot pass (20), so what enjoyment Allah gives yo do not accept? (21), from both we find pearls and diamond (22), so what enjoyment Allah gives you do not accept? (23), It is His, the ships going in the sea like the mountains (24)".

Besides those, we also find verse 36-59 meaning "so what enjoyment Allah gives you do not accept? (36), so if the sky is split and become red rose like the glitter of oil (37), so what enjoyment Allah gives you do not 
accept?(38), so, in the day, human beings and genies are not asked about their sins (39), so what enjoyment Allah gives you do not accept?(40), The sinners can be identified from the signs, then their crown of head and their legs are taken (41), so what enjoyment Allah gives you do not accept? (42), this is the hell of Jahanam hoped by the sinners (43), they go around there among the hot water (44), so what enjoyment Allah gives you do not accept? (45), and whoever are afraid in facing their Allah, there are two heavens (46), so what enjoyment Allah gives you do not accept? (47), the heavens have many kinds of trees and plants and fruits (48), so what enjoyment Allah gives you do not accept? (49), in the heavens there is two flowing water (50), so what enjoyment Allah gives you do not accept?(51), in the heavens there are fruits in parnertship (52), so what enjoyment Allah gives you do not accept? (53), they lay on carpet in which it is made from thick silk. And one can pick the fruits in heaven from the near (54), so what enjoyment Allah gives you do not accept? (55), in the heaven there are fairies who are not yet touched by men or genies before (56) so what enjoyment Allah gives you do not accept? (57) they are like beautiful jewels (58) so what enjoyment Allah gives you do not accept? (59)".

Then the researcher sees the verse 61-77 meaning "so what enjoyment Allah gives you do not accept? (61), and besides the two heavens there are two more (62), so what enjoyment Allah gives you do not accept? (63), those heavens look olg green (64), so what enjoyment Allah gives you do not accept?(65), in the heavens there are two source of water spout out (66), so what enjoyment Allah gives you do not accept? (67), in the heavens there are fruits and palm tress (68), so what enjoyment Allah gives you do not accept? (69). In the heavens there are good and beautiful fairies (70), so what enjoyment Allah gives you do not accept? (71), the fairies are kept in the camps (72) so what enjoyment Allah gives you do not accept? (73), human beings and genies have never touched the fairies before (74), so what enjoyment Allah gives you do not accept? (75), they lay on green pillows and beautiful carpets (76) so what enjoyment Allah gives you do not accept? (77). It is clear that all the verses contain Islamic education of Islamic history in many kinds of forms such the story of events or incidents in the past, the prophets, the friends of the 
prophet, and even the life in the heaven with all enjoyments human beings will accept.

\section{CONCLUSION}

Based on the discussion above, the researcher concludes that in Al-Qur'an Surah Ar-Rahman, we find Islamic education consisting of education of faith (Aqidah), education of Morality (Akhlak), education of Islamic law (Fiqih) and education of Islamic history (Tarikh). Education of faith (Aqidah) tells us about belief in the oneness of Allah which is manifested in six basic principle of Iman. Islamic Education of morality (akhlak) tells us about valu of goddness (keihsanan) and its regulation human beings must implement in their daily life. Islamic education of Islamic law (fiqih) tells us about Islamic law (syari'ah law) and its many kinds of regulation human beings must understand and implement in their life. Islamic education on the Islamic history which talk about the story on past events or incidents and the story of heaven and hell. All the elements of Islamic education are written in beautiful verses and various figurative languages so that it looks beautiful to listen.

\section{REFERENCE}

Abdullah, M. 2007. Tafsir Ibnu Katsir Jilid 13. Bogor: Pustaka Imam Asy-Syafi'i.

Ahmadi, Abu dan Nur Uhbiyati. 1991. Ilmu Pendidikan. Jakarta: Rineka Cipta.

Ali, Muhammad Daud. 2017. Pendidikan Agama Islam. Jakarta: Rajawali Press.

Al-Qattan, Manna' Khalil. 2000. Studi Ilmu-ilmu Qur'an. Bogor: Pustaka Litera Antar Nusa.

Al-Rosyid, dan Samsul Nizzar. 2003. Edisi Revisi Pendekatan Historis, Teoritis dan Praktis Filsafat Pendidikan Islam. Ciputat : PRESS, 2003.

Arifin, Imron (ed). 1994. Penelitian Kualitatif dalam Ilmu-ilmu Sosial dan Keagamaan. Malang: Kalimasada Press.

Arikunto, Suharsini. 1989. Prosedur Penelitian Suatu Pendekatan Praktek. Jakarta: Rineka Cipta.

Arikuntoro, Suharsimi. 2002. Prosedur Penelitian. Jakarta: Rineka Cipta. 
Ash Shiddieqy, Teungku Muhammad Hasbi. 2002. Al Bayan Tafsir Penjelas Al-Qur'anul Karim. Semarang: PT. Pustaka Rizki Putra.

Ash Shiddieqi, Teungku Muhammad Hasbi. 1997. Pengantar Hukum Islam. Semarang: Pustaka Riski Putra.

As-Suyuti, Imam. 2014. Asbabul Nuzul Sebab-sebab Turunnya Ayat AlQur'an. Jakarta Timur: Pustaka Al-Kautsar.

Az-Zuhaili, Wahbah. 2014. Tafsir Al-Munir. Aqidah, Syari'ah, \& Manhaj Jilid 14. Jakarta: Gema Insani.

Barqi, Ahmad bin Muhammad. 1371H. al-Mahāsin. Tehran: Darul Kutubul Islamiyah.

Budihardjo. 2012. Pembahasan Ilmu-Ilmu al-Qur'an. Yogyakarta: LOKUS.

Daradjad, Zakiah dkk. 2008. Ilmu Pendidikan Islam. Jakarta: Bumi Aksara.

http://quraishshihab.com/article/islam-dan-seni/. (diakses pada tanggal 25 Desember 2018)

Kallah, Abdul Wahhab. 2002. Kaidah-kaidah Hukum Islam, Ilmu Ushulul Fiqih. (Jakarta: Raja Grafindo Persada.

Koto, Alaiddin. 2004. Ilmu Fiqih dan Ushul fiqih. Jakarta: PT Raja Grafindo Persada.

M. Echols, John dan Hasan Shadily. 1982. Kamus Inggris Indonesia. Jakarta: PT. Gramedia Pustaka Utama.

Miles, Matthew B \& Michael Huberman. 1984. Analisi Data Kualitatifbahasa Tjejep Rohendi Rohidi. Jakarta: Universitas Indonesia.

Moleong, J. Lexy. 2017. Metodologi Penelitian Kualitatif. Bandung: PT. Remaja Rosdakarya.

Muhaimin Abdul Mujib, Pemikiran Pendidikan Islam: Kajian Filosofis dan Kerangka Dasar Operasionalisasinya, (Bandung: Trigenda Karya, 1993), h. 109-110.

Muhaimin. 2004. Wacana Pengembangan Pendidikan Islam. Yagyakarta: Pustaka Pelajar.

Mujib, Abdul dan Jusuf Mudzakkir. 2006. Llmu Pendidikan Islam. Jakata: Kencana Prenada Media.

Mulyono, Edi Dkk. 2012. Belajar Hermeneutika: Dari Konfigurasi Filosofis Menuju Praktis Islamic Studies. Jogjakarta: IRCiSoD. 
Munardji. 2004. Ilmu Pendidikan Islam. Jakarta: PT Bina Ilmu.

Nasir, Ridlwan dan Editor Adib Abdushomad. 2005. Mencari Tipologi Format Pendidikan Ideal. Yogyakarta: Pustaka Pelajar.

Nata, Abuddin. 2003. Masail al-Fiqihiyah. Bogor: Kencana.

Nata, Abuddin. 2004. Metodologi Studi Islam. Jakarta: Raja Grafindo Persada.

Nawawi, Hadari dan M. Martini Hadari. 1992. Instrumen Penelitian Bidang Sosial. Yogyakarta: Gadjah Mada University Press.

Nawawi, Hadasi. 1993. Pendidikan Islam. Surabaya: Al-Ihsan.

Nazir, Muhammad. 1986. Metode Penelitian. Bandung: Remaja Rosdakarya.

Nurgiyantoro, Burhan. 1998. Teori Pengkajian Fiksi. Yogyakarta: Gadjah Mada Univercity Press.

Ratna, Nyoman Kutha. 2004. Teori, Metode, dan Teknik Penelitian Sastra. Yogyakarta: Pustaka Pelajar.

RI, Departemen Agama. 2010. Al-Qur'an dan Tafsirnya, Jilid. IX. Jakarta: Lentera Abadi.

RI, Kementerian agama. 2014. Fiqih. Jakarta: Kementerian Agama.

Shihab, M. Quraish, et. All. 2008. Sejarah dan Ulum Al-Qur'an. Jakarta: Pusataka Firdaus.

Shihab, Quraish. 2009. Tafsir Al-Misbah, Ciputat: Lentera Hati.

Shihab, Quraish. 2012. Al-Lubab makna, tujuan, dan pelajaran dari surah-surah al-Qur'an, Ciputat: Lentera Hati.

Shofan, Muh. 2004. Pendidikan Berparadigma Profesik Upaya Konstruktif Membongkar Dikotomi Sistem Pendidikan Islam. Gresik : UMG Press.

Surachmad, Winarno. 1972. Pengantar Penelitian Ilmiah Dasar. Bandung: Tarsito.

Uhbiyati, Nur. 1998. Ilmu Pendidikan Islam. Bandung: Pustaka Setia.

W, Ahsin. 2008. Kamus Ilmu Al-Qur'an. Jakarta: Amzah.

Zuhairini. 2004. Metodologi Pembelajaran Pendidikan Agama Islam. Malang: UIN Press. 